\title{
Preface to the special issue Stochastic Financial Economics
}

\author{
Sjur Didrik Flåm • Klaus Reiner Schenk-Hoppé
}

Published online: 21 March 2012

C Springer-Verlag 2012

The special issue Stochastic Financial Economics (published in two parts, volume 1 and 2) relates to the international conference Stochastic Economics and Finance held in Bergen, Norway, 12-13 June 2011. The conference was sponsored by the Norwegian Finance Market Fund (project Stochastic Dynamics of Financial Markets, 2010-2012).

From the joint mission of the scientific meeting and the journal Mathematics and Financial Economics - the strengthening of the links between mathematics and economics and finance - the idea for this special issue was born. We thank the Editor-in-chief Ivar Ekeland and his predecessor Elyès Jouini for their initiative and support in publishing this special issue.

All papers have undergone the standard anonymous refereeing process of Mathematics and Financial Economics.

December 26, 2011

S. D. Flåm (殴

Economics Department, University of Bergen, Bergen, Norway

e-mail: sjur.flaam@econ.uib.no

K. R. Schenk-Hoppé $(\varangle)$

Leeds University Business School and School of Mathematics, University of Leeds,

Leeds, UK

e-mail: k.r.schenk-hoppe@leeds.ac.uk

K. R. Schenk-Hoppé

Department of Finance and Management Science, NHH-Norwegian School of Economics, Bergen, Norway 